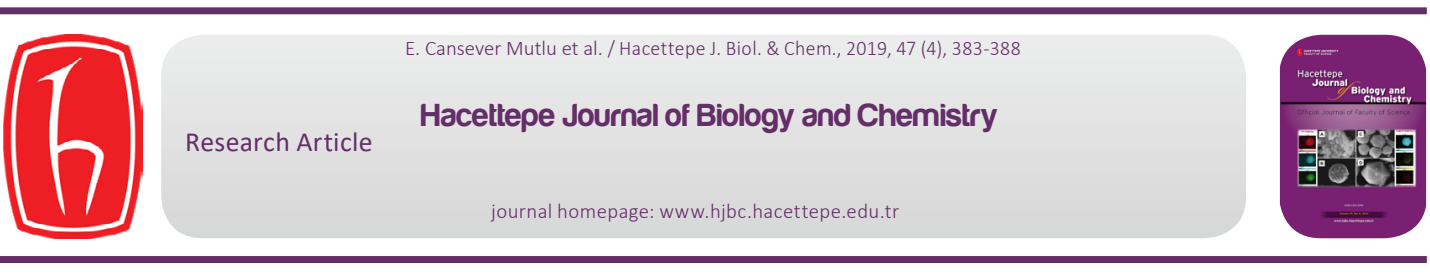

\title{
Exosome Production, Isolation and Characterization from A549 Epithelial Carcinoma Cells
}

\section{A549 Epitelyal Karsinom Hücrelerinden Eksozom Üretimi, İzolasyonu ve Karakterizasyonu}

\author{
Esra Cansever Mutlu ${ }^{1,2}$, Özge Kaya ${ }^{3 \oplus}$, Arzu Birinci Yildirim ${ }^{4 \oplus}$ and Ayhan Çetinkaya ${ }^{5}$ \\ ${ }^{1}$ Beykent University, Faculty of Engineering and Architecture, Department of Biomedical Engineering, Istanbul, Turkey. \\ ${ }^{2}$ Scientific Industrial and Technological Application and Research Center, Bolu Abant Izzet Baysal University, Bolu, Turkey. \\ ${ }^{3}$ Department of Biology, Faculty of Arts and Sciences, Bolu Abant Izzet Baysal University, Bolu, Turkey. \\ ${ }^{4}$ Department of Field Crops, Faculty of Agricultural and Natural Sciences, Bolu Abant Izzet Baysal University, Bolu, Turkey. \\ ${ }^{5}$ Department of Physiology, Faculty of Medicine, Bolu Abant İzzet Baysal University, Bolu, Turkey.
}

\begin{abstract}
- xosomes are natural nanoparticles that their special features as a natural, homogeneous, nanosized, targeted vesicles ( 50- $100 \mathrm{~nm}$ ) have started to be used in the treatment of cancer very recently They have high avidity (many conformational attachment) to attach onto targeted cancer cell surfaces. They are composed of bioactive double-layered lipid layers in which their original nature has the adhesive proteins interacting with the cancer cell membrane easily. In this study, the exosomes of non-small cell lung cancer, A549-epithelial carcinoma cells were investigated for their potential to be the natural or synthetic drug carrier. Firstly, exosomes of A549 cell line were produced using exosome-free media. Immediately after, isolation of their exosomes were performed by using ultracentrifugation procedure. Their SEM image, particle size and zeta potential measurements, exosomal RNA analysis and Protein Content by Bradford assays were performed. Findings (Size: $168 \mathrm{~nm}$; zeta: -16mV) on the properties of A549 cell exosomes proved their potential to be used as the drug carrier for cancer cell therapy.
\end{abstract}

\section{Key Words}

Exosome, ultracentrifugation, A549 cell Line, miRNA.

\section{öz}

Ekzosomlar, kanser tedavisinde doğal, homojen, nano boyutlu, hedeflenmiş veziküller ( 50 ila 100 nm) olarak özel özelliklerin son yıllarda kullanılmaya başlandığı doğal nanopartiküllerdir. Hedeflenen kanser hücresi yüzeylerine bağlanmak için yüksek bir aviditeye (birçok konformasyonel tutunmaya) sahiptirler. Özgün doğasında kanser hücresi membranı ile kolaylıkla etkileşebilen yapışkan proteinlere sahip olan biyoaktif çift-katmanlı lipit tabakalarından oluşurlar. Bu çalışmada, küçük hücreli olmayan A549 epitelyal kanser hücrelerinin ekzosomlarının doğal ya da sentetik ilaç taşıyıcı olabilme potansiyelleri araştıııldı. Öncelikle, ekzosom içermeyen ortamlarda üretilen A549 hücre dizisinin ekzosomları üretildi. Hemen sonrasında, ekzosomlarının izolasyonu ultrasantrifüj prosedürü kullanılarak yapıldı. SEM görüntü, partikül boyutu ve zeta potansiyel ölçümleri, exosomal RNA analizleri ve Bradford yöntemi ile protein içeriği analizi gerçekleştirildi. A549 hücrelerinin exozomlarının özelliklerine ilişkin bulgular (Boyut: 168 nm; zeta: -16mV), kanser hücresi terapisi için ilaç taşıyıcı olarak kullanılma potansiyellerini kanıtlamıştır.

\section{Anahtar Kelimeler}

Ekzosom, ultrasantrifüj, A549 hücre hattı, miRNA.

Article History: Received: Jan 31, 2019; Revised: Apr 20, 2019; Accepted: Jul 23, 2017; Available Online: Nov 1, 2019.

DOI: https://doi.org/10.15671/hjbc.520101

Correspondence to: Cansever Mutlu, Beykent University, Faculty of Engineering and Architecture, Department of Biomedical Engineering, Istanbul, Turkey.

E-Mail: esramutlu@beykent.edu.tr 


\section{INTRODUCTION}

- xosomes as extracellular vehicles below $100 \mathrm{~nm}$ are — composed of natural lipid bilayers and they are responsible for cellular functions between cells and their environments. Moreover, they have got many oncological vital functions when they are especially secreted by cancer entitled oncosomes [1, 2]. Not only they can interact cellular membranes easily via adhesive proteins on their surface, but also avoid entrapments of mononuclear phagocytes. This also represents their superior property for enhancing the delivery of incorporated drugs to desired cells by altering therapeutic efficiency. Therefore, exosomes now are one of the new hot topics in the subject of nanomedicine among cancer therapy studies $[3,4]$.

Lung cancer is one of the major health problems affecting too many people in all around the world. In 2012, the most common cancer type with $13 \%$ of occurrence frequency in the world was the lung cancer. At the same time, lung cancer is the most common cause of death, corresponding to $19.4 \%$ out of total cancer deaths in the world. Lung cancer is clinically based on the size and appearance of malignant cells; small cell lung (16.8\%) and non-small cell lung cancer (80.4\%) were divided into two main groups $[5,6]$.

Recently, it was indicated that the cancer cells secrete their characteristic exosomes which are not present among exosomes of healthy cells. Exosomes from tumor cells play vital role to suppress immune system components [7]. Interestingly, they can be larger (in micron diameters) than ones from normal cells vesicles termed oncosomes. However, they are desired to be obtained in diameters below $200 \mathrm{~nm}$.

In this study, we developed an isolation technique for the exosomes from A549 Epithelial carcinoma cells in order to evaluate their drug carrier potential according to their sizes and stabilities. Their miRNA, total RNA and protein content have been investigated due to the sufficiency of drug loading [3, 4, 8].

\section{MATERIALS and METHODS}

\section{Materials}

DMEM/F-12 (Dulbecco's Modified Eagle Medium/Nutrient Mixture F-12) is a widely used basal medium for supporting the growth of A549 Lung Cancer Cells, was purchased as PAN Biotec ${ }^{\top M}$. Fetal Bovine Serum (FBS) was obtained as BioSera ${ }^{\mathrm{TM}}$. Penicilin-Streptomycin (5000 U/mL), Trypsin-EDTA (0.25\% w/phenol red), PBS (phosphate buffered saline w/o Calcium Magnesium Phenol Red) were used Gibco, Thermo Fisher Scientific?? Ultracentrifuge tubes were purchased as HITACHI MODEL S303922A TM $^{\mathrm{TM}}$

\section{Pretreated Solutions}

- $\quad$ PBS, $\mathrm{ddH}_{2} \mathrm{O}, \mathrm{FBS}$ were subjected to ultracentrifugation to obtain ExoFreePBS, ExoFreeWater and ExoFreeFBS.

- After sterilization of ultracentrifuge tubes at $121^{\circ} \mathrm{C}$, each has fulfilled using PBS, water and FBS.

- After balance measurements, ultracentrifugation were performed overnight at $120.000 \mathrm{~g}$ [9].

Each tube had a volume of $8 \mathrm{~mL}$. Supernatant was collected gently after ultracentrifugation in order to be used during our further studies.

- $\quad$ Supernatant collected in another $15-\mathrm{mL}$ sterile falcon tubes and DexFreeFBS were kept $-20^{\circ} \mathrm{C}$ again. DexFreePBS and DexFreeWater were kept $+4^{\circ} \mathrm{C}$.

\section{Production of Exosomes}

- A549 Epithelial Lung Carcinoma Cells were obtained from Bolu Abant Izzet Baysal University, Department of Physiology stocks.

- $\quad$ Cells were grown under optimum full growth condition (DMEM-F12 90\%, 10\% DexFreeFBS, Antibiotic Solution (50 U. $\mathrm{mL}^{-1}$ penicillin, and $50 \mathrm{mg} \cdot \mathrm{mL}^{-1}$ streptomycin), 0.5\% Amphotericin in $\mathrm{t} 25$ flask).

- After 3 days in a $5 \% \mathrm{CO}_{2}$ humid atmosphere at $37^{\circ} \mathrm{C}$, cells were transferred to TPPTM t75 flasks for optimal full growth condition by using Tripsin-EDTA and PBS.

- $\quad$ After 3 passages, 6,23×103 cells were obtained in each t75 media. Cell Counting were performed by using Bio-Rad's TC20 ${ }^{\mathrm{TM}}$ Cell Counter.

\section{Isolation of Exosomes}

- $\quad$ Cells were transferred into centrifuge tubes. After centrifugation at $300 \mathrm{~g}$ for $15 \mathrm{~min}$ at $4^{\circ} \mathrm{C}$, cell pellets were removed.

- $\quad$ Supernatants were transferred into 8-mL ultracentrifuge tubes placed in dry ice. Immediately after ultra-centrifugations were performed at $17.000 \mathrm{~g}$ to eliminate cell debris completely.

- $\quad$ Supernatants were filtered by sterile syringe through sterile $0.2-\mu \mathrm{m}$ filters to remove larger particles 


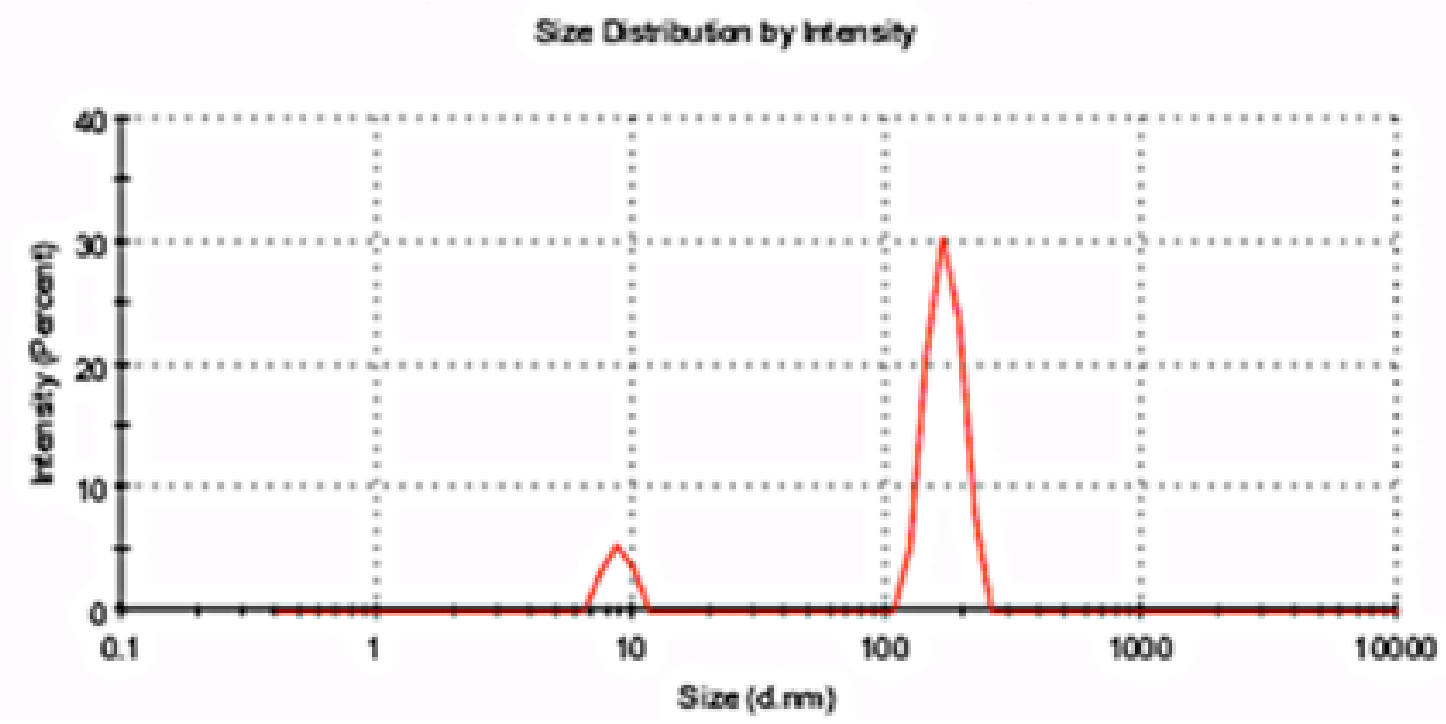

Figure 1. Size distribution of Exosomes from A549 Lung Cancer Cell Line.

more than $200 \mathrm{~nm}$ [10].

- $\quad$ Filtered part were transferred to new sterile ultracentrifuge tubes. Ultracentrifugation was performed at $120.000 \mathrm{~g}$ for 60 minutes at $4^{\circ} \mathrm{C}$.

- Pellet (Exosomes) were resuspended by ExoFree BPS by $(3 \times 50 \mu \mathrm{L})$ to sterile cryotubes.

- $\quad$ Cryotubes were kept at $-80^{\circ} \mathrm{C}$ for exosome analysis.

\section{SEM Analysis}

Cryotubes containing exosomes were left to melt down at room temperature. A sample from each tube was dropped using sterile Pasteur pipettes onto metal grids with double sided adhesive carbon tape. After they are dried at room temperature, coated with gold to $\sim 500 \times 10^{-8} \mathrm{~cm}$ in thickness using sputter coater under high vacuum, $0.1 \mathrm{Torr}, 1.2 \mathrm{kV}$, and $50 \mathrm{~mA}$ at $27 \pm 1^{\circ} \mathrm{C}$. The surface morphology of coated samples was evaluated by scanning electron microscopy (SEM), Leica ${ }^{\mathrm{TM}}(2)[4]$.

\section{Zeta/Size Analyses}

Cryotubes were left to melt down at room temperature. Each tube was diluted using $2 \mathrm{~mL}$ ExoFree PBS and measurements were performed by Malvern Nanosizer/ Zetasizer nano-ZS ZEN 3600. Completely disposable dip-cell cuvettes were used during measurements [4].

\section{Extraction and Quantification of Exosomal RNA}

In order to evaluate the exosomal RNA content; two column base commercial RNA isolation kits were used namely innuPREP RNA Minianalytik ${ }^{\mathrm{TM}}$ (Jena, Germany) for total RNA extraction and miRNA ${ }^{\mathrm{TM}}$ (Omega Bio-tek, Inc, Guangzhou, China) kit for miRNA extraction. $30 \mu \mathrm{L}$ of exosome samples suspended in DexFree PBS were mixed with lysis buffer of the each kit and manufacturer's instructions are followed. Isolated RNA molecules were eluted from the columns by centrifuge method as described their procedures by using nuclease-free water. Total RNA and miRNA quantification measurements were carried out by using QuantiFluor ${ }^{\circledR}$ RNA Dye on fluorometry (Quantus ${ }^{\mathrm{T}} 2$ Fluorometer, Promega ${ }^{\circledR}$, Madisson, USA) and Thermo Scientific / $2000{ }^{\text {TMNanodrop. }}[4,9]$ and Nuclease free water used as the control. During the extraction whole working area was cleaned with the "RNase-ExitusPlus" from AppliChem and all the materials used for RNA extraction was nuclease-free in order to prevent RNase contamination.

\section{Analysis of Protein Content}

Total protein content of the A549 exosome samples suspended in DexFreePBS were evaluated with Bradford (1976) [11] method by using Pierce ${ }^{\mathrm{TM}}$ Coomassie (Bradford) Protein Assay Kit. The amount of total protein was measured colorimetrically at $595 \mathrm{~nm}$ using a UV/Vis spectrophotometer (Jasco V-530 UV/Vis spectrophotometer, Jasco International Corporation, Tokyo, Japan) and was quantified as Bovine serum albumin equivalent (BSA) value. 


\section{Zeja Polertía Distibuton}

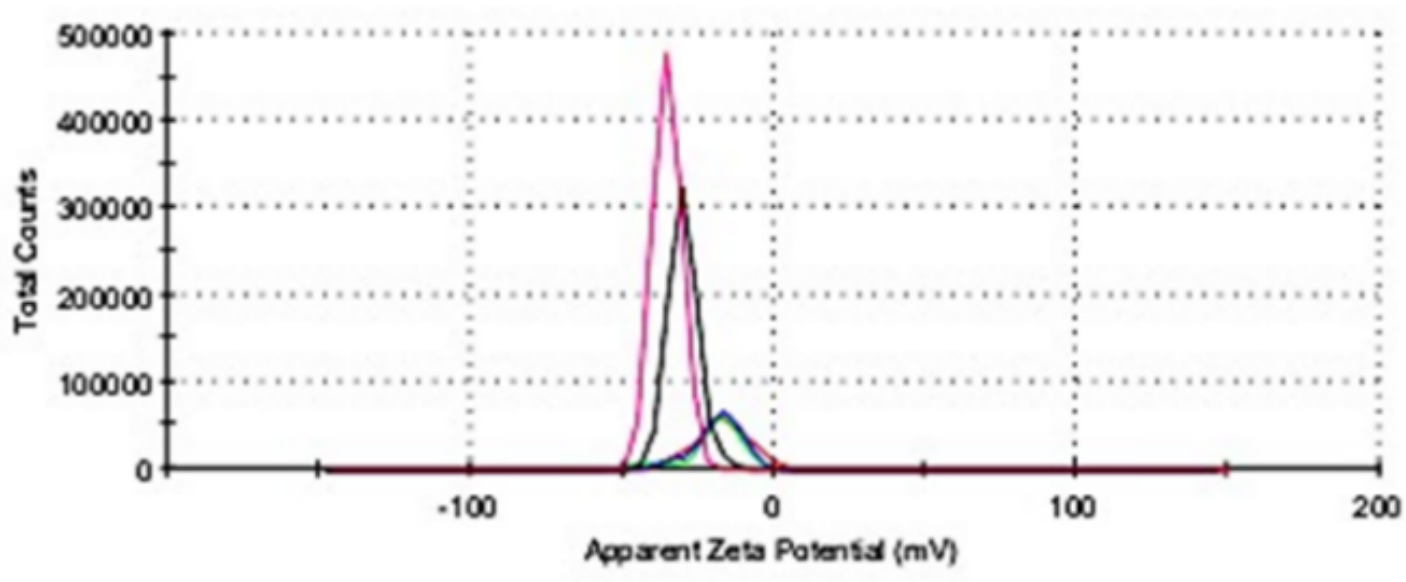

Figure 2. Zeta Potential of Exosomes from A549 Lung Cancer Cell Lines.

\section{RESULTS and DISCUSSION}

Size/zeta measurements of exosomes were performed in order to prove its drug delivery potential with respect to their dimensions and stabilities. Size distribution of exosomes displayed bimodal dispersion (Figure 1). The distribution of first peak is $168.3 \pm 25.8 \mathrm{~nm}$; second peak is $8.83 \pm 0.9 \mathrm{~nm}$. While, intensity of first peak is $\% 87.9$; intensity of the second peak is $\% 12.1$.

Zeta potential measurement showed that the exosome of A549 Lung Cancer Cell Line was $-16 \pm 8.72 \mathrm{mV}$ (Figure2).

SEM images showed that the exosomes of A549 cell lines have the distribution between $\sim 50-150 \mathrm{~nm}$ (Figure 3). Images proved that coagulation has poor and the exosomes are highly durable even at $70^{\circ} \mathrm{C}$. After $80^{\circ} \mathrm{C}$, their spherical structures converted into more rigid structures.

RNA could not be detected in miRNA measurements. In the exosomes samples obtained from A549 cells, 4.5 $\mathrm{ng} / 106$ cell total RNA was detected, while RNA was not detected in the control sample with fluorometric measurements. Bradford (1976) [11] method was used to determine the exosomal protein concentration. So, exosome samples of A549 cells were measured protein content equivalent to $13.2 \mu \mathrm{g} / 106$ cells of BSA. No protein was detected in the control (DexFreePBS) samples. In this study, the potential of promising usage of exosomes from A549 cell lines were investigated for their drug loading capacities for probable use in cancer therapy as the next strategy $[12,13]$. Thereby, we evaluated all the results to enlighten the material properties of natural nanoparticles, exosomes, of A549 cell line. According to our findings, all exosomes are quite small ( $\leq 200 \mathrm{~nm}),(-16 \mathrm{mV})$ and have lowest amount of RNA content. The prospective challenge would be that they have highly protein content before drug loading.

In fact, even clinical study was performed previously [14]. Although a few studies in the literature were carried out to produce exosomes of A549 cell line from microvesicles (MVs), there is no spotlight exosomal study of this cancer line searching for their sizes, zeta, image analysis and molecular content such as miRNA, totalRNA and protein contents [15].

\section{CONCLUSION}

Cancer cell exosomes has the great potential for cancer therapy, this perspective brings with many unknown questions for therapy. Steric stabilization and $\mathrm{pH}$ effects of them are of note to change general phenomen for zeta potential measurements. Our results showed that exosomes of A549 cell line $-16 \mathrm{mV}$. This circumstance showed chemical structure of A549 cell line exosomes should be investigated as the prospective study to enlighten protein content of their surface which may affect zeta potential value. Nonetheless, exosomes of A549 cell line has the great potential for synthetic drug loading by sonication method; for, they are spherically durable even at $70^{\circ} \mathrm{C}$. These results, has been displa- 


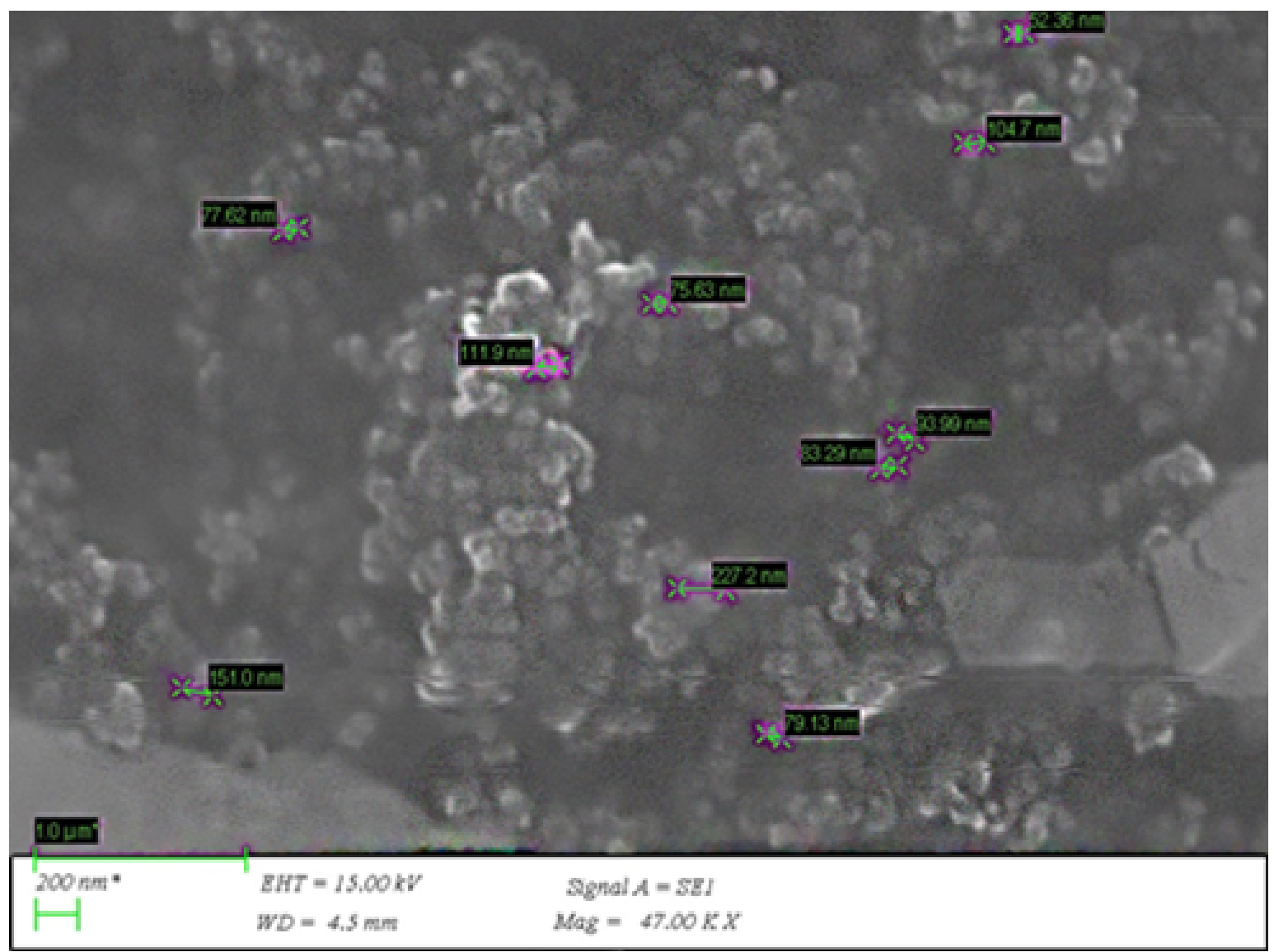

Figure 2. Zeta Potential of Exosomes from A549 Lung Cancer Cell Lines.

yed the new research quide and the method article for A549 cell line exosomes in cancer therapy.

\section{Acknowledgments}

Authors thank to Bolu Abant İzet Baysal University Research Fund through BAP Project 2018.31.01.1359.

\section{References}

1. G. Mignot, S. Roux, C. Thery, E. Ségura, L. Zitvogel, Prospects for exosomes in immunotherapy of cancer, J. Cell. Mol. Med., 10 (2006) 376-388.

2. M. Morello, V. Minciacchi, P. De Candia, J. Yang, E. Posadas, H. Kim, D. Griffiths, N. Bhowmick, L. Chung, P. Gandellini, Large oncosomes mediate intercellular transfer of functional microRNA, Cell cycle, 12 (2013) 3526-3536.

3. P. Vader, X. O. Breakefield, M. J. Wood, Extracellular vesicles: emerging targets for cancer therapy, Trends. Mol. Med., 20 (2014) 385-393.

4. M. S. Kim, M. J. Haney, Y. Zhao, V. Mahajan, I. Deygen, N. L. Klyachko, E. Inskoe, A. Piroyan, M. Sokolsky, O. Okolie, Development of exosome-encapsulated paclitaxel to overcome MDR in cancer cells, Nanomed-Nanotechnol., 12 (2016) 655-664.
5. A. Jemal, R. Siegel, E. Ward, Y. Hao, J. Xu, T. Murray, M. J. Thun, Cancer statistics, 2008, CA: a cancer journal for clinicians, 58 (2008) 71-96.

6. R. Siegel, C. DeSantis, A. Jemal, Colorectal cancer statistics, 2014, CA: a cancer journal for clinicians, 64 (2014) 104-117.

7. C. Théry, M. Ostrowski, E. Segura, Membrane vesicles as conveyors of immune responses, Nat. Rev. Immunol., 9 (2009) 581.

8. J. Palma, S. C. Yaddanapudi, L. Pigati, M. A. Havens, S. Jeong, G. A. Weiner, K. M. E. Weimer, B. Stern, M. L. Hastings, D. M. Duelli, MicroRNAs are exported from malignant cells in customized particles, Nucleic Acids Res., 40 (2012) 91259138.

9. S. El-Andaloussi, Y. Lee, S. Lakhal-Littleton, J. Li, Y. Seow, C. Gardiner, L. Alvarez-Erviti, I.L. Sargent, M.J. Wood, Exosomemediated delivery of siRNA in vitro and in vivo, Nat. Protoc., 7 (2012) 2112.

10. C. Lässer, M. Eldh, J. Lötvall, Isolation and characterization of RNA-containing exosomes, Jove-J. Vis. Exp., (2012).

11. M.M. Bradford, A rapid and sensitive method for the quantitation of microgram quantities of protein utilizing the principle of protein-dye binding, Anal. Biochem., 72 (1976) 248-254.

12. W. Li, D. Mu, F. Tian, Y. Hu, T. Jiang, Y. Han, J. Chen, G. Han, $X$. Li, Exosomes derived from Rab27a-overexpressing tumor cells elicit efficient induction of antitumor immunity, Mol. Med. Rep., 8 (2013) 1876-1882. 
13. M. Wysoczynski, M.Z. Ratajczak, Lung cancer secreted microvesicles: underappreciated modulators of microenvironment in expanding tumors, Int. J. Cancer, 125 (2009) 1595-1603.

14. M.A. Morse, J. Garst, T. Osada, S. Khan, A. Hobeika, T.M. Clay, N. Valente, R. Shreeniwas, M. A. Sutton, A. Delcayre, A phase I study of dexosome immunotherapy in patients with advanced non-small cell lung cancer, J. Transl. Med., 3 (2005) 9
15. Y.T. Tang, Y.-Y. Huang, L. Zheng, S.-H. Qin, X.P. Xu, T.X. An, Y. Xu, Y.S. Wu, X.M. Hu, B.H. Ping, Comparison of isolation methods of exosomes and exosomal RNA from cell culture medium and serum, Int. J. Mol. Med., 40 (2017) 834-844. 